\title{
Detection of Bonamia ostreae and $B$. exitiosa (Haplosporidia) in Ostrea edulis from the Adriatic Sea (Italy)
}

\author{
V. Narcisi ${ }^{1}$, I. Arzul ${ }^{2}$, D. Cargini ${ }^{1}$, F. Mosca ${ }^{1}$, A. Calzetta ${ }^{1}$, D. Traversa ${ }^{1}$, M. Robert ${ }^{2}$, \\ J. P. Joly ${ }^{2}$, B. Chollet ${ }^{2}$, T. Renault ${ }^{2}$, P. G. Tiscar ${ }^{1, *}$ \\ ${ }^{1}$ Department of Comparative Biomedical Sciences, University of Teramo, P. A. Moro 45, 64100, Teramo, Italy \\ ${ }^{2}$ Laboratoire de Génétique et Pathologie, Institut français de recherche pour l'exploitation de la mer (IFREMER), \\ Ronce les Bains, 17390 La Tremblade, France
}

\begin{abstract}
The flat oyster Ostrea edulis L. is widespread along the Italian coasts. In particular, the Manfredonia Gulf (Adriatic Sea) represents an important site where natural beds subsist. Previous monitoring conducted in 1990 by light microscopy and ultrastructural studies revealed the presence of Bonamia-like microcell parasites in some flat oysters: following this observation, a new sampling of $O$. edulis was carried out at this location in 2007. Of 750 oysters collected, 3 showed the presence of uninucleated microcells ( 2 to $3 \mu \mathrm{m}$ diameter) free or inside the haemocyte cytoplasm by cytology and histopathology. Molecular analysis confirmed that the microcells in 2 oysters were $B$. exitiosa, whereas in the third oyster the microcells were $B$. ostreae. Moreover, molecular studies were carried out to confirm the existence of Bonamia sp. in archived samples, confirming the presence of B. ostreae in the Manfredonia Gulf since 1990.
\end{abstract}

KEY WORDS: Bonamia spp. · Ostrea edulis $\cdot$ Molecular analysis $\cdot$ Electron microscopy

\section{INTRODUCTION}

Ostrea edulis L. is the native European oyster species whose production has historically represented an economically important activity in several European countries, including France, Ireland, the UK, the Netherlands, and Spain (Grizel 1985, Culloty \& Mulcahy 1996, Abollo et al. 2008). In Italy, natural beds of $O$. edulis are present along the Adriatic coast, where they are occasionally fished and directly sent to trade or, in some cases, left as stocks waiting for better trade periods. Moreover, in recent years experimental farming of Crassostrea gigas has been developed.

Considering the importance of the commercial exchanges of live mollusc stocks around the world and the associated risk of disease spread from affected to free areas, the zoosanitary control of transfers is essential. It is thus necessary to establish the health status of the oyster production areas and to characterize the pathogens.

The genus Bonamia encompasses protistan parasites causing a disease of oyster haemocytes responsible for extensive oyster mortality; the bonamiosis in Ostrea edulis caused declines in the flat oyster production along European Atlantic coasts in the late 1970s and early 1980s (Comps et al. 1980, Tigè et al. 1980). The presence of haplosporosomes (Pichot et al. 1980, Hine et al. 2001) and the molecular analysis of the small subunit rRNA (SSU rRNA) gene (Carnegie et al. 2000, Cochennec et al. 2000, Cochennec-Laureau et al. 2003, Carnegie \& Cochennec-Laureau 2004, Reece et al. 2004) placed, phylogenetically, the genus Bonamia in the phylum Haplosporidia. Four characterized species are included in this genus: B. ostreae, B. exitiosa, B. roughleyi (OIE 2006), and B. perspora. B. ostreae (Pichot et al. 1980) occurs naturally in O. edulis L. (Grizel et al. 1983). 
Bonamia exitiosa infects Ostrea chilensis in New Zealand (Hine et al. 2001) and O. angasi in Australia (Corbeil et al. 2006) and has been recently reported in O. edulis in Spain (Abollo et al. 2008). B. roughleyi, previously called Mikrocytos roughleyi, infects Saccostrea glomerata in southeast Australia (Farley et al. 1988). B. perspora is a newly described protozoan species found in Ostreola equestris (North Carolina, USA) and represents the first Bonamia species producing a typical haplosporidian spore (Carnegie et al. 2006). Other B. exitiosa-like organisms have been described in O. chilensis from Chile (Kern 1993, Campalans et al. 2000), O. puelchana from Argentina (Kroeck \& Montes 2005), and Crassostrea ariakensis from North Carolina (Burreson et al. 2004); these organisms have been subsequently declared $B$. exitiosa (Lopez-Flores et al. 2007).

Previous studies have reported by microscopic and ultrastrustural means the occurrence in Italy of small parasites similar to Bonamia sp. in flat oysters collected from the southern (Tiscar et al. 1991) and northern Adriatic Sea (Tiscar et al. 2002). A small number of molluscs appeared infected by the parasites $(1 / 161$ from the southern and 8/600 from the northern Adriatic Sea, respectively). Nevertheless all the infected oysters showed high infection level of the haemocytes with the presence of numerous protozoans per cell (Tiscar et al. 1991, 2002).

Taking into account these previous reports, the aim of the present study was to investigate by cytology and histology the occurrence of microcell parasites in flat oysters Ostrea edulis newly collected from natural beds in the southern Adriatic Sea and to characterize the recovered parasites by molecular and ultrastructural analyses as well as to confirm and characterize the presence of Bonamia sp. in one positive sample collected during 1990 from the Manfredonia Gulf (Tiscar et al. 1991).

\section{MATERIALS AND METHODS}

Sample collection. A total of 750 flat oyster Ostrea edulis specimens were collected in February, May, July, September, and November 2007 (n = $150 \mathrm{mo}^{-1}$ ) from a dispatch center where the locally fished bivalves are normally carried. The oysters were fished from natural beds widespread in the Manfredonia Gulf. The Manfredonia Gulf consists of a large bay, located south of the Gargano Promontory, in the Southern Adriatic Sea inside the Mediterranean Sea (Fig. 1). Moreover, one paraffin-block embedded sample (coded as 1640), obtained through a sampling carried out in the Manfredonia Gulf in 1990, was included in the molecular studies, and some pictures acquired by transmission electron microscopy (TEM) in the previous research were re-analysed (Tiscar et al. 1991).

Microscopical examination. Each oyster was opened, and several heart imprints were made on a glass slide. Slides were air-dried, fixed in methanol, and stained using a commercial kit (Hemacolor ${ }^{\circledR}$; Merck). Then, all slides were observed at $1000 \times$ magnification.

Sections of tissue including gills, digestive gland, mantle, and gonad were fixed in phosphate-buffered formalin $10 \%$. The positive samples resulting from cytology examination were processed for paraffin histology. Thin sections $(5 \mu \mathrm{m})$ were cut from paraffin blocks and stained with haematoxylin and eosin (H\&E) for standard histopathological evaluation.

Molecular procedure. Gill fragments (25 mg) from each oyster were fixed in $95 \%$ ethanol. Genomic DNA was extracted from histological positive samples using a QIAamp ${ }^{\circledR}$ DNA Mini Kit (QIAGEN) following the manufacturer's instructions. Moreover, the DNA was extracted from Sample 1640 following the manufacturer's instructions to isolate DNA from paraffin block. DNA was resuspended in sterile, deionised water in order to produce a final DNA concentration of

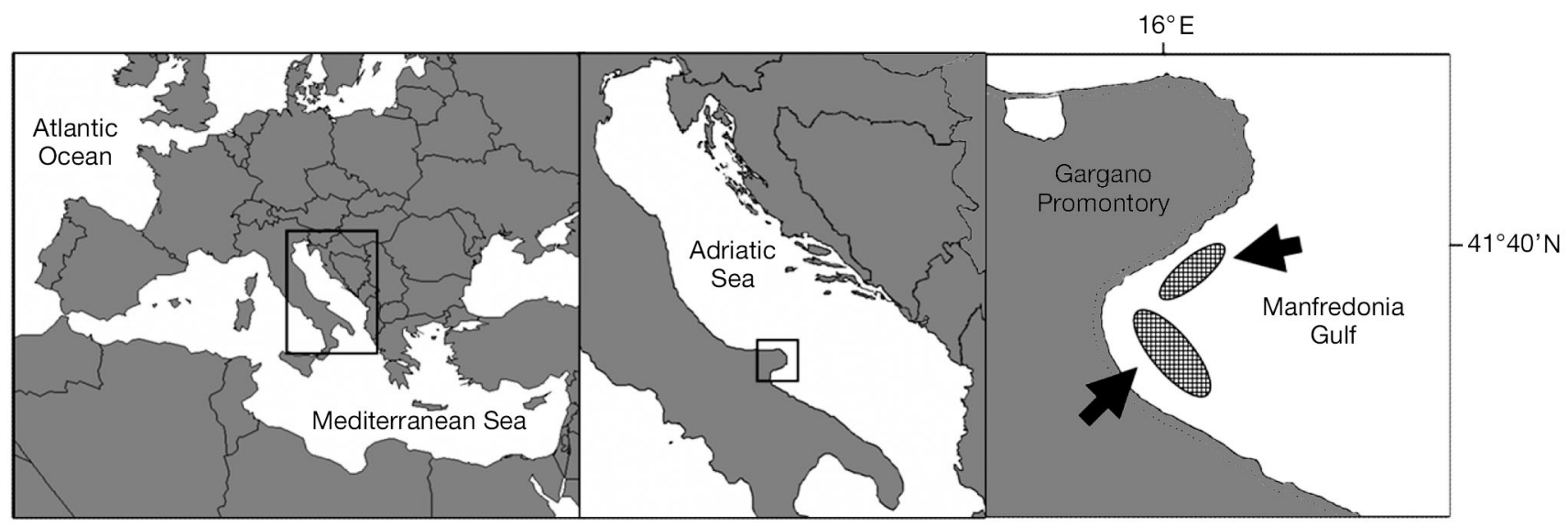

Fig.1. Manfredonia Gulf. Black arrows (right panel) indicate the main reported sites of the Ostrea edulis natural beds 
$100 \mathrm{ng} \mathrm{ul}^{-1}$. Extracts were stored at $4^{\circ} \mathrm{C}$ until PCR analyses were performed.

DNA extracts were subjected to the PCR amplification of the partial SSU rDNA using the Bonamia primer pair Bo-Boas (Cochennec et al. 2000). PCR was performed in $50 \mu$ l volume in REDTaq $^{\circledR}$ Mix (Sigma) containing $0.5 \mu \mathrm{l}$ of each primer $(100 \mathrm{mM})$ and $100 \mathrm{ng}$ of DNA. Negative control consisted of distilled water $(1 \mu \mathrm{l}$ for $49 \mu \mathrm{l}$ of PCR Mix), whereas the positive one contained DNA extracted from oysters known to be heavily infected by B. ostreae (supplied by Institut français de recherche pour l'exploitation de la mer [IFREMER], La Tremblade, France).

PCR reactions were carried out in a GenAmp PCR System 2700 thermocycler (Applied Biosystems). The cycling protocol was $94^{\circ} \mathrm{C}$ for $7 \mathrm{~min} ; 30$ cycles: $94^{\circ} \mathrm{C}$ for $1 \mathrm{~min}, 55^{\circ} \mathrm{C}$ for $1 \mathrm{~min}$, and $72^{\circ} \mathrm{C}$ for $1 \mathrm{~min}$; final elongation was at $72^{\circ} \mathrm{C}$ for $10 \mathrm{~min}$.

Additionally, the internal transcribed spacer (ITS)-1 region of 2 samples, coded as 29/07 and 77/09, was amplified using ITS For-8 and ITS Rev-8 primers (Corbeil et al. 2006); PCR cycling conditions were as follows: $7 \mathrm{~min}$ at $95^{\circ} \mathrm{C}$ for denaturation and 40 cycles: $30 \mathrm{~s}$ at $94^{\circ} \mathrm{C}, 45 \mathrm{~s}$ at $50^{\circ} \mathrm{C}$, and $45 \mathrm{~s}$ at $72^{\circ} \mathrm{C}$. Final elongation at $72^{\circ} \mathrm{C}$ was extended for $10 \mathrm{~min}$. After amplification, $10 \mu \mathrm{l}$ of the PCR products were separated by electrophoresis in $1.5 \%$ agarose gel (in tris-acetate-EDTA buffer $1 \times$ ), and the gels were stained with ethidium bromide.

Sequence determination and comparison. PCR products obtained from the infected samples and from the paraffin block were further purified using Ultrafree-DA columns (Millipore) and directly sequenced by MWG Biotech/M-Medical (Milan). PCR products obtained from one sample (29/07) were cloned using the TA cloning kit (Invitrogen), and 3 clones were bidirectionally sequenced using the BigDye V3 sequencing kit (Applied Biosystems), specific and plasmidic primers (TopoF: 5'-GAC CAT GAT TAC GCC AAG C-3' and TopoR: 5'-CCC AGT CAC GAC GTT G-3'). Sequences were searched for similarity with public databases lodged in GenBank (Benson et al. 2008) using BLAST (basic local alignment search tool).

Ultrastructural studies. Two samples found positive by PCR (29/07 and 77/09) were processed for TEM. Gill tissue in phosphate-buffered formalin $10 \%$ were fixed with $4 \%$ glutaraldehyde. The samples were postfixed for $1 \mathrm{~h}$ in $1 \%$ osmium tetroxide $\left(\mathrm{OsO}_{4}\right)$ in $0.2 \mathrm{M}$ cacodylate buffer, cleared in propylene oxide, and embedded in epon resin. Ultrathin sections were obtained using copper grids and double-stained with $5 \%$ uranyl acetate and 5\% lead citrate and then examined at $120 \mathrm{kV}$ on a JEOL 1110 transmission electron microscope equipped with a Morada digital camera and analySIS imaging software (Soft Imaging System).

\section{RESULTS}

\section{Microscopic studies}

Three oyster specimens (29/07, 77/09, and 78/11), collected in July, September, and November, respectively, were considered infected by cytology and histopathology since they presented small spherical organisms within the cytoplasm of haemocytes or free in connective tissue and gills (Fig. 2). Examination of heart imprints showed intracellular or free organisms with basophilic cytoplasm and eosinophilic nucleus inside the haemocytes (Fig. 2a)

Histopathology showed few parasites in each oyster associated with focal haemocyte infiltrations in the connective tissue of the gill and mantle, and in the vascular sinuses around the stomach and the intestine. Parasitized haemocytes had an eccentric nucleus (Fig. 2b), and 1 or 2 parasites were observed inside the cytoplasm (Fig. 2b-d). The parasites were basophilic, spherical, or ovoid, and 2 to $3 \mu \mathrm{m}$ in diameter. Some parasites were observed free in the connective tissue (Fig. 2c,d).

\section{Ultrastructural studies}

The samples (29/07 and 77/09) selected for ultrastructural studies showed dense and intermediate forms of Adriatic Bonamia sp. In dense forms, the nucleus appeared central and nearly circular in section, consisting of a finely granular and electron-dense nucleoplasm and containing a dense nucleolus located peripherally, often seen against the nuclear membrane. The cytoplasm presented mitochondria (Fig. 3a), Golgi bodies composed of stacked saccules and small vesicles, lipid bodies (Fig. 3b), haplosporosomes with the characteristic double membrane (Fig. 3c), and many ribosomes spread in the cytoplasm (Fig. 3a,c). Spheroid inclusions (Fig. 3a) were also present: these elements could correspond with different haplosporogenesis stages. Mitochondrial size and shape were variable, even in the same section, with sparse vesicular inclusions or membranous features (Fig. 3a). A stage containing large vacuoles derived from enlargement of one or more mitochondria has been observed in some sections (Fig. 3a). Quantitative data from electron micrographs of cells are given in Table 1. The comparison of Adriatic Bonamia sp. with B. ostreae showed some differences; the latter is smaller and has larger haplosporosomes, and fewer lipoid bodies and mitochondrial profiles. However, the mean number of $B$. ostreae haplosporosemes is closer to that of the Adriatic Bonamia sp. than B. exitiosa. The Adriatic Bonamia sp. presented similarity with $B$. exitiosa in cell diameter and mitochondria number (Table 1). 


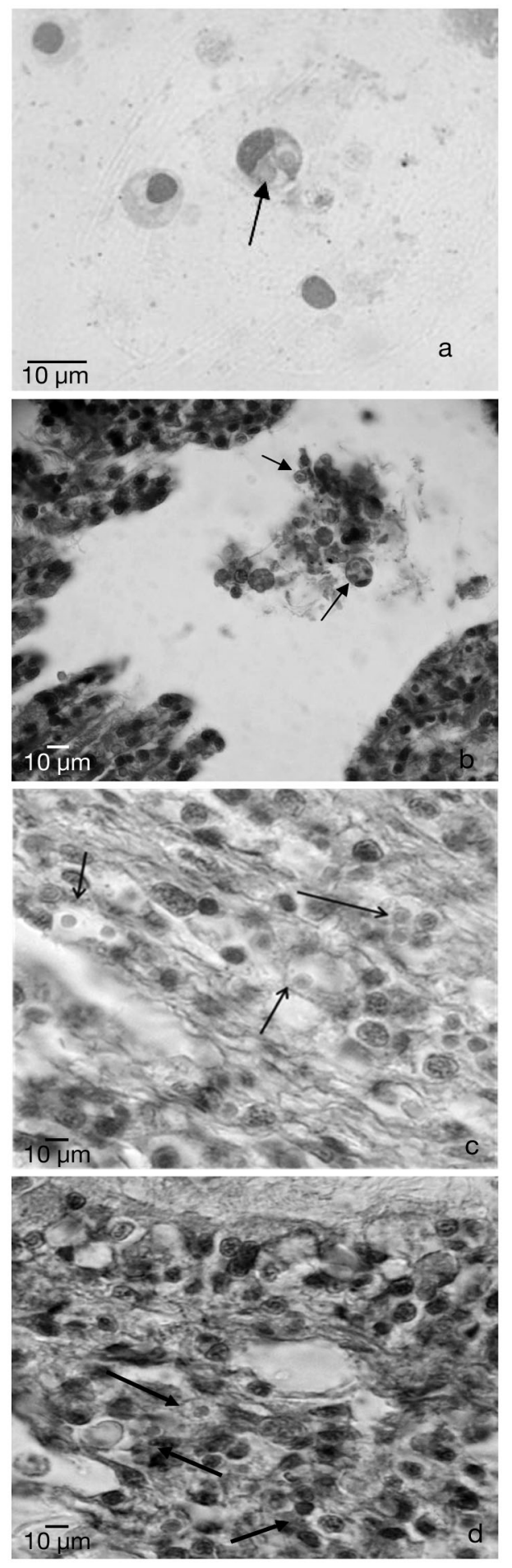

Fig. 2. Bonamia sp. infecting Ostrea edulis. (a) Heart imprint from $O$. edulis $(29 / 07)$. Some uninucleated cells, 2 to $5 \mu \mathrm{m}$ wide, can be observed within the cytoplasm of a haemocyte (arrow); Hemacolor ${ }^{\circledR}$ staining. (b) Histological section from O. edulis (29/07). Some uninucleated microcells can be observed within haemocytes and extracellularly (arrows) in water lacuna in gills. (c) Microcells in connective tissue, and (d) within haemocytes and extracellularly in gills (arrows). Haematoxylin and eosin (H\&E) staining
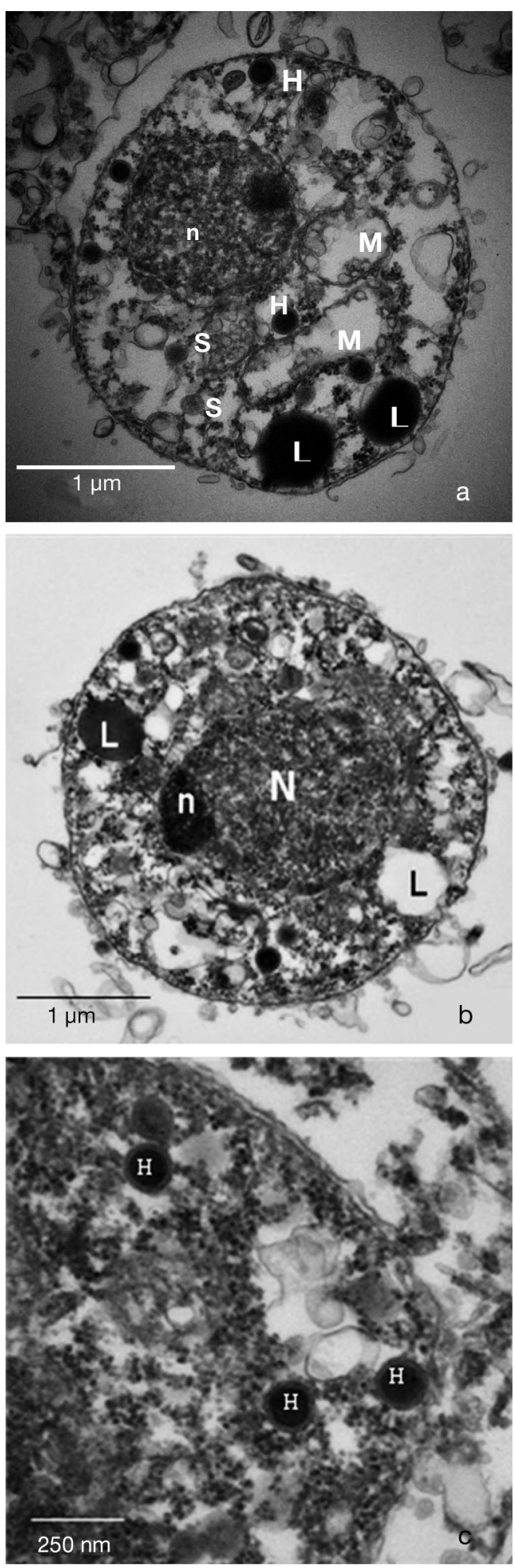

Fig. 3. Bonamia sp. infecting Ostrea edulis. (a) Vacuolated form showing enlarged mitochondria $(\mathrm{M})$, eccentric nucleus (n), lipoid bodies (L), haplosporosomes $(\mathrm{H})$, and spheroid inclusions (S). (b) Dense form with N, an eccentric nucleolus (n), and L. (c) H exhibiting double membrane within cytoplasm of Bonamia sp. dense form 
Table 1. Bonamia spp. Comparison of the main features of the dense forms (mean \pm SD)

\begin{tabular}{|c|c|c|c|c|c|c|c|c|c|}
\hline \multirow[t]{3}{*}{ Species } & \multirow{3}{*}{$\begin{array}{c}\text { No. } \\
\text { examined }\end{array}$} & \multirow{3}{*}{$\begin{array}{c}\text { Diameter } \\
\quad(\mu \mathrm{m})\end{array}$} & \multirow{3}{*}{$\begin{array}{l}\text { No. of } \\
\text { mitoch- } \\
\text { ondria }\end{array}$} & \multicolumn{3}{|c|}{ Haplosporosomes } & \multicolumn{2}{|c|}{ Lipoid bodies } & \multirow[t]{3}{*}{ Source } \\
\hline & & & & No. & Diame & $\mathrm{r}(\mathrm{nm})$ & Present & No. & \\
\hline & & & & & Mean & Range & $(\%)$ & & \\
\hline $\begin{array}{l}\text { Bonamia sp. } \\
\text { (Ostrea. edulis } \\
\text { Adriatic Sea) }\end{array}$ & is 62 & $3 \pm 0.3$ & $3 \pm 0.2$ & $7.2 \pm 4.3$ & $132 \pm 21$ & $73-257$ & 30 & $0.4 \pm 0.08$ & Present study \\
\hline B. ostreae & 64 & $2.4 \pm 0.5$ & $2 \pm 1$ & $7 \pm 5$ & $153 \pm 18$ & $127-187$ & 7 & $0.3 \pm 0.6$ & Hine et al. (2001) \\
\hline B. exitiosa & 61 & $3 \pm 0.3$ & $3 \pm 1$ & $14 \pm 6$ & $148 \pm 11$ & $128-184$ & 49 & $0.8 \pm 0.9$ & Hine et al. (2001) \\
\hline
\end{tabular}

\section{PCR amplification and sequence analysis}

When PCR was performed using the primer pair Bo-Boas, amplicons of $300 \mathrm{bp}$ were obtained for 3 samples collected in 2007 (29/07, 77/09, 78/11) and for the DNA extracted from the paraffin block 1640 (Fig. 4).

The PCR products were directly sequenced. In addition, the PCR products obtained from individual 29/07 were cloned, and 3 clones were sequenced in order to evaluate intra-oyster polymorphism of the fragment Bo-Boas. The sequence obtained from the DNA extracted from the paraffin block of Sample 1640 and the sequence obtained from one sample (78/11) confirmed the presence of Bonamia ostreae with $100 \%$ nucleotide homology.

The sequences obtained directly from the PCR products from Samples 29/07 and 77/09 and the sequences obtained from the 3 clones from Samples 29/07 were identical (nucleotide sequence data is available in the GenBank (Benson et al. 2008) (accession \#EU598800). The alignment of the sequences with the SSU rDNA genes of different Bonamia sp. showed $100 \%$ homol-

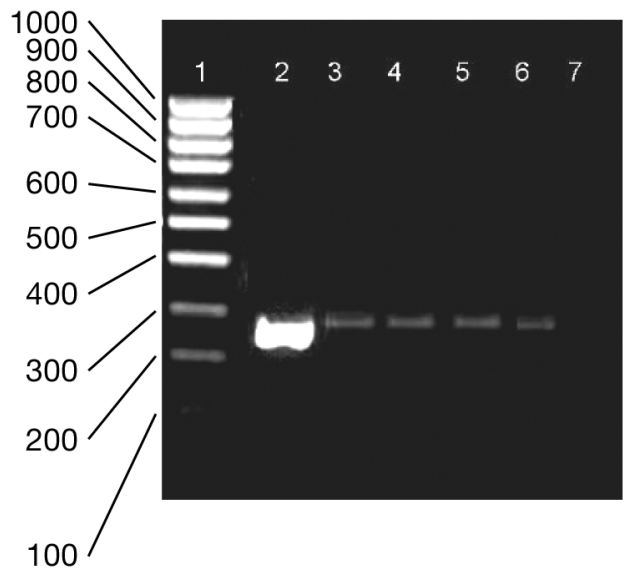

Fig. 4. Bonamia ostreae. Agarose gel electrophoresis of PCR products with primer pair Bo-Boas. Lane 1: $100 \mathrm{bp}$ molecular weight marker; Lane 2: DNA from purified B. ostreae; Lane 3: DNA from Sample 29/07; Lane 4: DNA from Sample 77/09; Lane 5: DNA from Sample 78/11; Lane 6: DNA from Sample 1640; Lane 7: negative control ogy in both samples with $B$. exitiosa, such as those from Australia (\#DQ312295); Bonamia sp. NAS-2004 found in Crassostrea ariakensis, Bogue Sound, North Carolina (\#AY542903); Bonamia sp. Ca 1-16 (\#AY923857) found in C. ariakensis and Bonamia sp. found in Ostrea chilensis in New Zealand (\#AF337563).

The PCR using primers ITS For-8 and Rev-8 from Samples 29/07 and 77/09 produced an amplicon of about $100 \mathrm{pb}$ (nucleotide sequence data is available in the GenBank accession \#EU672891). Alignment of the obtained ITS fragments presents further evidence of the genetic identity of the Adriatic isolate with Australian Bonamia exitiosa (\#DQ312295).

\section{DISCUSSION}

The present study demonstrated the presence of protozoa belonging to the genus Bonamia in flat oysters Ostrea edulis from the Adriatic Sea and, particularly, from the Manfredonia Gulf. Two Bonamia spp. were detected. Molecular analyses showed identities with B. ostreae in one sample as well as in the older oyster sample preserved in paraffin block, thus confirming the existence of this species in the Manfredonia Gulf since 1990 (Tiscar et al. 1991). Moreover, the DNA sequence analysis supported, in 2 samples, the occurrence of microcells belonging to $B$. exitiosa, thus corroborating the recent report of this species in European flat oysters (Abollo et al. 2008). B. exitiosa is known to infect $O$. chilensis in New Zealand (Dinamani et al. 1987) and O. angasi in Australia (Hine \& Jones 1994, Hine 1996, Corbeil et al. 2006), while other parasites, referred to as $B$. exitiosa (Lopez-Flores et al. 2007), have been reported in O. chilensis in Chile (Campalans et al. 2000), in O. puelchana in Argentina (Kroeck \& Montes 2005), and in Crassostrea ariakensis in North Carolina, USA (Burreson et al. 2004).

An ultrastructural study was carried out to morphologically characterize the microcell belonging to Bonamia exitiosa occurring in Italy, but the ultrastructural characteristics were so variable that they cannot be used to definitively identify a Bonamia species. 
A previous study reported the presence of haemocytic parasites in oysters collected from the same site (Tiscar et al. 1991): the authors, on the basis of the ultrastructural characteristics, classified the parasite as belonging to Bonamia sp. In one picture, electrondense material was included between 2 membranes around the parasite, but the exact significance of this structure is still not well defined. Unfortunately, at the moment it is not possible to carry out further ultrastructural studies on this sample. Morphological studies performed on the Bonamia parasites for many years have excluded the existence of resistance forms inside the genus. Nevertheless, the presence of sporulation stages has been recently observed in $B$. perspora, suggesting that other Bonamia spp. may also produce spores (Carnegie et al. 2006).

The use of molecular tools in the present study has allowed us to confirm that the protozoan parasite found in oysters collected during 1990 corresponds to Bonamia ostreae and not to Haplosporidium species. The comparative molecular analysis with sequences available in GenBank showed that Adriatic Bonamia sp. from Samples 29/07 and 77/09 was identical to B. exitiosa, suggesting that Adriatic microcells belong to the same species. The third sample (78/11) investigated by PCR showed $100 \%$ homology with $B$. ostreae, thus confirming the presence of 2 Bonamia spp. in the Manfredonia Gulf as reported in Spain (Abollo et al. 2008).

Due to the lack of previous data, it cannot be determined whether Bonamia exitiosa was present in the Adriatic flat oyster in the past years or if it was recently introduced. Consequently, some questions arise about the origin of the Adriatic B. exitiosa.

In Italy, a large import of bivalves, mainly represented by Japanese oysters and mussels from other European countries, including Spain, where Bonamia exitiosa was recently reported in Ostrea edulis (Abollo et al. 2008), is present and might have contributed to the spread of the parasite. However, epidemiological studies are needed to answer the question.

Bonamia sp. was previously reported in Ostrea edulis collected in the northern Adriatic Sea in 1997, 1998, and 2000. In 1997, a total of 8 oysters out of the 300 analysed showed the presence of round and nucleated elements of 2 to $3 \mu \mathrm{m}$ (Tiscar et al. 2002). The molecular analysis conducted on these samples by Bo-Boas primers, revealed identity with $B$. ostreae (data not shown). Therefore, B. ostreae has been present in Adriatic Sea over the past years, but its real impact is difficult to evaluate since data on the population density of $O$. edulis natural beds are lacking.

Moreover, substantial differences in environmental conditions exist between the Adriatic Sea (Mediterranean Sea) and the Atlantic Ocean, thus possibly inducing a different development of the parasite. In the Manfredonia Gulf, the seawater average tem- perature is $16.8^{\circ} \mathrm{C}$, with higher temperatures in August (ca. $27^{\circ} \mathrm{C}$ ) and minimum temperatures in January (ca. $10^{\circ} \mathrm{C}$ ) whereas the salinity is $37.34 \mathrm{~g} \mathrm{l}^{-1}$ (Sistema Difesa Mare 2007). These data are comparable with information about Quiberon Bay in the Atlantic Ocean, where bonamiosis is endemic: the yearly temperature mean is $14.56^{\circ} \mathrm{C}$, with a maximum in August (ca. $23^{\circ} \mathrm{C}$ ) and a minimum in January (ca. 5 to $10^{\circ} \mathrm{C}$ ). The yearly salinity mean is $33.47 \mathrm{~g} \mathrm{l}^{-1}$, with a maximum in August of $38 \mathrm{~g} \mathrm{l}^{-1}$; Bonamia ostreae has been present in Quiberon Bay since 1980, with prevalence usually lower than $0.15 \%$ (Arzul et al. 2005). A recent study on the influence of environmental factors showed a better survival of purified $B$. ostreae in hyper-saline (>35 g $\mathrm{l}^{-1}$ ) than in hyposaline media $\left(<20 \mathrm{~g} \mathrm{l}^{-1}\right)$; moreover, high temperature $\left(>25^{\circ} \mathrm{C}\right)$ seems to have a negative impact on the parasite survival (Arzul et al. 2007).

The presence of Bonamia ostreae and B. exitiosa in natural beds in the Manfredonia Gulf did not seem to cause mass mortality. The longtime presence of pathogens in flat oysters living in natural beds and the different environmental parameters of the Adriatic Sea could have induced a balanced host-parasite relation. In a number of other shellfish diseases, the only potential long-term method of control has been the development of resistance in the host species. 'Resistance' in bivalve generally refers to relatively greater survival, thus implying a reduced susceptibility to the presence of the parasite and allowing the oysters to reach to market size before disease-induced mortalities occur (Ford 1986).

In fact, some studies have suggested that differences might exist between European populations of Ostrea edulis in regard to their susceptibility to infection with Bonamia ostreae (Culloty et al. 1999). For example, Rossmore oysters (Cork Harbour, Ireland) exposed to the parasite throughout life showed lower prevalence of infection and percentage mortality than other Irish strains exposed to the parasite in the laboratory and in the field (Culloty et al. 2004).

In conclusion, 2 listed parasites, Bonamia ostreae and $B$. exitiosa, are present at low prevalence in oysters originating from Adriatic Sea. New epidemiological data are required to determine the distribution of Bonamia spp. in European waters and to avoid the spread of these pathogens. Moreover, further studies need to be carried out on the Adriatic Ostrea edulis resource in order to elucidate the parasite-host interactions.

\section{LITERATURE CITED}

\footnotetext{
Abollo E, Ramillo A, Casas SM, Comesana P, Cao A, Carballal MJ, Villalba A (2008) First detection of the protozoan parasite Bonamia exitiosa (Haplosporidia) infecting flat oyster Ostrea edulis grown in European waters. Aquaculture 274:201-207
} 
Arzul I, Miossec L, Blanchet E, Garcia C, Francois JP, Berthe F (2005) A long-term study of bonamiosis in Quiberon bay, France. 8th Int Conf Shellfish Restoration, Brest, France 2-5 October 2005. IFREMER, La Tremblade

Arzul I, Bond C, Gagnaire B, Morga B and others (2007) Flow cytometry to measure impact of temperature and salinity on the survival of Bonamia ostreae, parasite infecting flat oyster Ostrea edulis, in seawater. 13th Int Conf Fish Shellfish Diseases, 17-21 September 2007, Grado, Italy, EAFP (poster)

Benson DA, Karsch-Mizrachi I, Lipman DJ, Ostell J, Wheeler DL (2008) GenBank. Nucleic Acids Res 36 (Database issue):D25-D30

Burreson E, Stokes N, Carnegie R, Bishop M (2004) Bonamia sp. (Haplosporidia) found in nonnative oysters Crassostrea ariakensis in Bogue Sound, North Carolina. J Aquat Anim Health 16:1-9

Campalans M, Rojas P, Gonzalez M (2000) Haemocytic parasitosis in the farmed oyster Tiostrea chilensis. Bull Eur Assoc Fish Pathol 20:31-33

- Carnegie R, Cochennec-Laureau N (2004) Microcell parasite of oysters: recent insight and future trends. Aquat Living Resour 17:519-528

Carnegie RB, Barber BJ, Culloty SC, Figueras AJ, Distel DL (2000) Development of a PCR assay for detection of the oyster pathogen Bonamia ostreae and support for its inclusion in the Haplosporidia. Dis Aquat Org 42:199-206

Carnegie RB, Burreson EM, Hine PM, Stokes NA, Audemard C, Bishop MJ, Peterson CH (2006) Bonamia perspora n. sp. (Haplosporidia), a parasite of the oyster Ostreola equestris, is the first Bonamia species known to produce spores. J Eukaryot Microbiol 53:232-245

Cochennec N, Le Roux F, Berthe F, Gerard A (2000) Detection of Bonamia ostreae based on small subunit ribosomal probe. J Invertebr Pathol 76:26-32

Cochennec-Laureau N, Reece KS, Berthe FCJ, Hine PM (2003) Mykrocytos roughleyi taxonomic affiliation leads to the genus Bonamia (Haplosporidia). Dis Aquat Org 54: 209-217

Comps M, Tigè G, Grizel H (1980) Recherches ultrastructurales sur un protiste parasite de l'huitre plate Ostrea edulis. C R Hebd Seances Acad Sci Ser D Sci Nat 290: 383-384

Corbeil S, Arzul I, Robert M, Berthe FCJ, Cochennec NB, Crane MSJ (2006) Molecular characterisation of an Australian isolate of Bonamia exitiosa. Dis Aquat Org 71: 81-85

> Culloty SC, Mulcahy MF (1996) Season-, age-, and sexrelated variation in the prevalence of bonamiasis in flat oysters (Ostreae edulis) L. on the south coast of Ireland. Aquaculture 144:53-63

Culloty SC, Novoa B, Pernas M, Longshaw M, Mulcahy MF, Feist SW, Figueras A (1999) Susceptibility of a number of bivalve species to the protozoan parasite Bonamia ostreae and their ability to act as vectors for this parasite. Dis Aquat Org 37:73-80

Culloty SC, Cronin MA, Mulcahy MF (2004) Potential resistance of a number of populations of the oyster Ostrea edulis to the parasite Bonamia ostreae. Aquaculture 237: 41-58

Editorial responsibility: Eugene Burreson, Gloucester Point, Virginia, USA
Dinamani P, Hickman R, Hine P, Jones J, Cranfield H (1987) Report on investigations into the disease outbreak in Foveaux Strait oysters, Tiostrea lutaria, 1986-1987. Ministry of Agriculture and Fisheries, Wellingtion

Farley CA, Wolf PH, Elston R (1988) A long-term study of 'microcell' disease in oysters with a description of a new genus, Mikrocytos (g.n.) and two new species, Mikrocytos mackini (sp.n.) and Mikrocytos roughleyi (sp. n.). Fish Bull 86:581-593

Ford SE (1986) Comparison of haemolimph proteins from resistant and susceptible oysters Crassostrea virginica exposed to the parasite Haplosporidium nelsoni (MSX). J Invertebr Pathol 47:283-294

Grizel H (1985) Étude des récentes épizooties de l'huîtres plate Ostrea edulis L. et de leur impact sur l'ostreiculture Bretonne. Thèse de Doctorat, Universitè des Sciences Techniques du Languedoc, Montpellier

Grizel H, Comps M, Raguenes D, Leborgne Y, Tigè G, Martin AG (1983) Bilan des essais d'acclimatation d'Ostrea chilensis sur les côtes de Bretagne. Rev Trav Inst Pêches Marit 46:209-225

Hine PM (1996) The ecology of Bonamia and decline of bivalve molluscs. NZ J Ecol 20:109-116

Hine PM, Jones JB (1994) Bonamia and other aquatic parasites of importance to New Zealand. NZ J Zool 21: 49-56

> Hine PM, Cochennec-Laureau N, Berthe FCJ (2001) Bonamia exitiosa n.sp. (Haplosporidia) infecting flat oysters Ostrea chilensis in New Zealand. Dis Aquat Org 47:63-72

Kern FG (1993) Shellfish health inspections of Chilean and Australian oysters. J Shellfish Res 12:366

- Kroeck MA, Montes J (2005) Occurrence of haemocyte parasite Bonamia sp. in flat oysters Ostrea puelchana farmed in San Antonio Bay (Argentina). Dis Aquat Org 63:231-235

Lopez-Flores I, Suarez-Santiago VN, Longet D, Saulnier D, Chollet B, Arzul I (2007) Characterization of actin genes in Bonamia ostreae and their application to phylogeny of the Haplosporidia. Parasitology 134:1941-1948

OIE (Office International des Epizooties) (2006) Manual of diagnostic tests for aquatic animals, 5th edn. OIE, Paris

Pichot Y, Comps M, Tigè G, Grizel H, Rabouin MA (1980) Recherches sur Bonamia ostrea gen. n. sp. n. parasite nouveau de l'huître plate Ostreae edulis L. Rev Trav Inst Pêches Marit 43:131-140

Reece KS, Siddall ME, Stokes NA, Burreson EM (2004) Molecular phylogeny of the Haplosporidia based on two independent gene sequences. J Parasitol 90:1111-1122

Sistema Difesa Mare (Si.Di.Mar) (2007) Ministero dell'ambiente e della tutela del territorio e del mare. www.sidimar. ipzs.it. (accessed 1 December 2007)

Tigé G, Grizel H, Comps M (1980) Données sur le nouveau parasite de l'huître plate. Situation épidemiologique. Cons Int Explor Mer CM 1980/F:39

Tiscar PG, Zizzo N, Tempesta M (1991) Su alcune patologie riscontrate in ostriche piatte (Ostrea edulis) provenienti da banco naturale. Boll Soc Ital Pathol Ittica 7:13-18

Tiscar PG, Quaglio F, Della Salda L, Ceschia G, Delgado Montero ML, Restani R (2002) Presenza di Bonamia ostreae in ostriche piatte (Ostrea edulis) del Nord Adriatico. Boll Soc Ital Pathol Ittica 35:2-10

Submitted: January 9, 2009; Accepted: October 15, 2009

Proofs received from author(s): February 4, 2010 